\title{
The assessment of influence of different nitrogen compounds and time on germination of Lupinus angustifolius seeds and chemical composition of final products
}

\author{
Małgorzata Kasprowicz-Potocka*, Ewa Walachowska, Anita Zaworska, Andrzej Frankiewicz \\ Department of Animal Nutrition and Feed Management, Poznań University of Life Sciences, Wołyńska 33, 60-637 Poznań, Poland
}

\section{Abstract}

The aim of the research was to determine changes in the chemical composition in lupin seeds during seed germination in a solution containing selected nitrogen compounds. Blue lupin seeds of the Neptun cultivar were germinated for 3 or 4 days in darkness, at $24^{\circ} \mathrm{C}$ in $1 \%$ solutions containing the following nitrogen compounds: urea, nitric acid, ammonium sulphate, methionine or yeast extract. The control consisted of seeds germinated in water. The presence of all nitrogen sources has resulted in a poorer growth of the sprouts as compared to seeds germinated in water. There was a significant increase in the true protein content as well as a significant decrease in the content of crude ash and alkaloids in the germinated seeds. The seeds germinated for 4 days had significantly higher total protein content and significantly lower content of nitrogen-free extract compounds and oligosaccharides as compared to the seeds germinated for 3 days. A significant influence of the nitrogen source on the concentration of some amino acids was found. Cystine was found to be absent in seeds germinated in the nitric acid solution, while there occurred a twofold increase in the cystine content and a fivefold increase in the methionine content in seeds germinated in the aqueous solution of methionine and an 50\% increase in the cystine concentration was observed in seeds germinated in the yeast extract and ammonium sulphate solution. Methionine and cystine were the limiting amino acids in all the samples, accept of seeds germinated in the methionine solution were it was valine. Aqueous solutions of ammonium sulphate and yeast extract were found to have the most advantageous influence on the chemical composition of lupin germination products.

Keywords: lupin, germination, N-sources, nutritional value

\section{Introduction}

Feed protein deficit has been a problem in Poland and Europe for years. The deficits are supplemented by importing soybean meal, which increases the feeding costs, thus contributing to the lower profitability of animal breeding [1]. Native leguminous plants can compete with soy; however, their nutritional value is limited by antinutrients, low digestibility of raw seeds and a low level of sulphur-containing amino acids [2]. Therefore, it is necessary to limit the use of unprocessed leguminous seeds in farm animal feeding. An improvement in the nutritional value can be obtained by mechanical, physical and barothermal treatment; however, these processes are expensive and they lower the content of some antinutrient substances without having a positive effect on the amino acid content and profile

\footnotetext{
*Corresponding author. Email: malgokas@poczta.onet.pl Handling Editor: Grażyna Kłobus

This is an Open Access digital version of the article distributed under the terms of the Creative Commons Attribution 3.0 License (creativecommons.org/licenses/by/3.0/), which permits redistribution, commercial
} and non-commercial, provided that the article is properly cited. of the protein [3]. To improve protein quality, natural biological processes can be used including fermentation or germination [4-6]. The global annual production of consumer sprouts from beans only is estimated at approx. 40 million tons per year [7]. Germination causes significant chemical changes in the seeds, such as a higher content of proteins, vitamins, antioxidants with a simultaneous decrease in the antinutrient content $[5,6,8,9]$. Seeds are usually germinated hydroponically in the so-called aqueous culture, which limits the use of pesticide and product contamination and also eliminates allergens. In this case, only water is provided to the plant without any additional mineral substances and owing to the substances accumulated in the seeds, the development occurs more rapidly than in soil. The availability of water and oxygen, the ambient temperature and the germination time are the basic factors conditioning the effectiveness of the germination process. During the germination process, no protein substances are lost, only changes in the chemical composition of nitrogen compounds occur and the protein level increases, which is accompanied by an increase in the content of amino acids and other nitrogen compounds. The research, which has been conducted on lupin so far, has shown a positive influence of germination on the protein content and a decrease in the concentration of alkaloids (by approx. 30\%) and oligosaccharides (by approx. 80\%) [5,9]. The research conducted by Chilomer et al. [6] showed that lupin seed germination did not have a positive influence on feed digestibility and feed use 
by growing animals as compared to raw seeds, which was caused by a low nutritional value of the protein.

The rate of plant development and the chemical composition may be affected by the presence of various chemical compounds in the environment, which, depending on their chemical characteristics or concentration, may affect the seeds as germination stimulators or inhibitors. It has been shown that salts added during the germination process at appropriate small concentrations (fractions or a few \%) may have a stimulatory effect on the seeds, while these compounds can be toxic in large doses [10-16]. It is also possible to enrich sprouts with minerals (e.g. selenium) by introducing salt solutions into the environment $[17,18]$. In particular, nitrogen is indispensable for plant growth. Under natural conditions, nitrogen bound in soil may occur in the form of four compound types - ammonium salts $\left(\mathrm{NH}_{4}^{+}\right)$, nitrates $\left(\mathrm{NO}_{3}^{-}\right)$, proteins and products of their decomposition (amino acids, amines, peptides and humus compounds). Therefore, it seems that lupin seed germination in solutions containing an appropriate source of nitrogen could cause advantageous changes in the seed structure, thus probably improving their nutritional value and usefulness as feed. No data are available in the literature concerning the influence of the type and quantity of nitrogen compounds on the chemical composition of germinated seeds in the nutrient and antinutrient aspect [19]. The aim of the preliminary research was to define changes in the chemical composition of lupin seeds under the influence of the germination process conducted for 3 or 4 days in an aqueous solution containing the following selected nitrogen compounds: urea, nitric acid, ammonium sulphate, methionine and yeast extract at a $1 \%$ concentration.

\section{Material and methods}

\section{Samples and chemicals}

Blue lupin of Neptun cultivar lupin seeds was selected for the research. Urea (POCH, Gliwice), nitric acid (POCH, Gliwice), ammonium sulphate (POCH, Gliwice), methionine ( $98 \%$ of pure amino acid; Ajinomoto) and yeast extract containing $64.5 \%$ of total protein (MERCK, Germany) were used to prepare the $1 \%$ nitrogen solutions. The amino acid composition of yeast extract protein (g/100 g of protein) was: alanine 8.8, lysine 8.0, arginine 5.1, methionine 1.4, aspartic acid 9.9, phenylalanine 3.7, cystine 0.9 , proline 4.0 , glutamic acid 16.3 , serine 4.6 , glycine 4.8 , threonine 4.3 , histidine 2.1 , tyrosine 2.4 , isoleucine 5.5, tryptophan 1.3 , leucine 7.6 , valine 5.9.

\section{Germination}

The seeds were disinfected by soaking in a $0.09 \%$ sodium hypochlorite solution for 15 minutes, and next in deionized water until a neutral $\mathrm{pH}$ value was obtained and stored in a bag at room temperature. Portions of seeds (approx. 200 seeds in each) were placed in glass containers and soaked in deionized water for six hours to swell. The seeds were germinated in two repetitions in Bio-natura germination dishes equipped with an aeration, hydration and draining system. The germination process was conducted in darkness in an incubator at $23-24^{\circ} \mathrm{C}$. During the first 24 hours, the seeds were germinated only in water in all experiments, and next the seeds were watered twice a day with water or $1 \%$ aqueous solutions of the selected chemical preparations, depending on the variant. The excess of the solution was removed from the containers each time, which ensured appropriate moisture levels in the dishes. After days 3 and 4 , the seeds were rinsed with deionized water to remove the residues of the solutions and impurities and they were dried at $55^{\circ} \mathrm{C}$ until approx. $95 \%$ dry mass was obtained and they were then milled using a Retch laboratory mill. During the experiment, the effectiveness of the sprout growth, the smell and the color of the rinsed solution were observed. Only germinated seeds were selected for chemical analyses.

\section{Chemical analysis}

Raw and germinated seeds were analyzed in duplicate for dry matter (DM), crude protein (CP), fat (F), crude fiber (CF), and ash using AOAC [20] methods 934.01, 976.05, 920.39, $978.10,942.05$, respectively. For chemical analysis, the samples were grounded to pass through a $0.5-\mathrm{mm}$ sieve. Nitrogen-free extracts (NFE) were calculated. The amino acid content was determined using a type AAA-339 Mikrotechnia Amino Acid Analyzer using ninhydrin for postcolumn derivatization. Before analysis, samples were hydrolyzed with $6 \mathrm{~N} \mathrm{HCl}$ for 24 $\mathrm{h}$ at $110^{\circ} \mathrm{C}$ (procedure 994.12). Methionine and cystine were determined as methionine sulfone and cysteic acid after cold perfomic acid oxidation before hydrolysis (procedure 994.12, alternative 3). Phytate content was analyzed according to methods 986.11. The protein biological value was determined by means of indexes: $C S$ - the index of limiting amino acid, calculated with use of Mitchel and Block's method, EAAI - the index of exogenous amino acids calculated with the use of Oser's method. Tryptophane concentration was taken from tables. Lupin alkaloids were extracted from flour by trichloroacetic acid and methylene chloride. Determination was provided by GC method (Shimadzu GC17A) with capilar column (Phenomenex). Raffinose family oligosaccharides were extracted and analyzed by high-resolution gas chromatography as described previously Zalewski et al. [21].

\section{Statistical analysis}

A two-way analysis of variance (ANOVA) was used for statistical testing - the germination time and the source of nitrogen and the interactions between them were used as experimental factors. The significance of differences was analyzed using Tukey's test, at $P<0.05$. The STATGRAPHICS statistical package ver. 5.0 (USA) was used for statistical analysis.

\section{Results}

The organoleptic evaluation showed that approx. 95\% of seeds had germinated in water (Fig. 1). The length of sprouts was 40

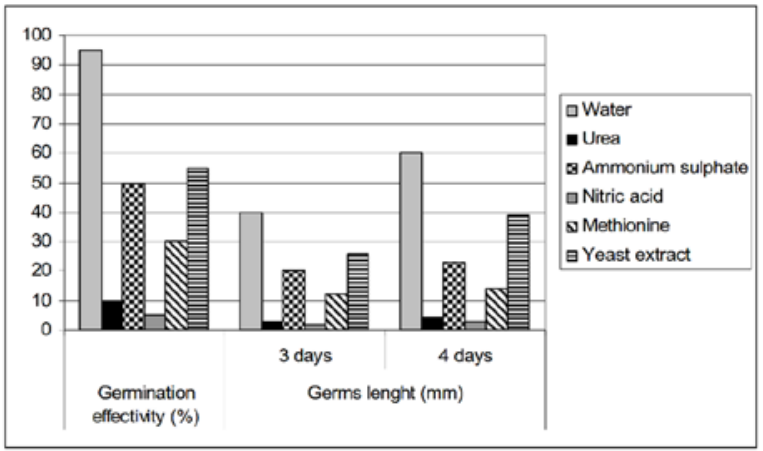

Fig. 1 The comparison of germination affectivity (\%) and length of germs $(\mathrm{mm})$ after 3 and 4 days of germination in water or $1 \%$ solutions of nitrogen compounds. 
and $60 \mathrm{~mm}$ on the $3 \mathrm{rd}$ and on the 4 th day, respectively. The seeds germinated in water were characterized by a specific odor and the rinsed solution had a light yellow color and it was cloudy. The germination rate was the lowest in the $1 \%$ urea and nitric acid solutions (5-10\%), they were poorly formed, misshapen and they reached a length of only a few millimeters. The seeds germinated in a urea solution were characterized by an intense odor of ammonia and the rinsed solution was yellow-greenish and cloudy. The seeds germinated in the nitric acid, on the other hand, had a light color and the rinsed solution was light and clear with an odor reminiscent of "sweet cherry compote". The seeds in the methionine solution germinated at a slightly better rate (approx. 30\%), reaching the average length of 12 and $14 \mathrm{~mm}$ on the $3 \mathrm{rd}$ and 4 th days of germination. The seeds germinated in a methionine solution had an odor reminiscent of sauerkraut and the rinsed solution was light yellow. The seeds in the ammonium sulphate and in the yeast extract had the highest germination rate (approx. 50\% and 55\%, respectively) with the length of sprouts of approx. 20 and $23 \mathrm{~mm}$ (ammonium sulphate) and 26 and 39 $\mathrm{mm}$ (yeast extract) on the $3 \mathrm{rd}$ and 4 th days, respectively. These sprouts were the best formed, without deformities and they were thicker than the remaining sprouts. The seeds germinated in a $1 \%$ ammonium sulphate solution had a specific odor and the rinsed solution was cloudy and greenish-grey in color, while seeds germinated in a $1 \%$ yeast extract solution were characterized by a specific, slightly fermented yeast odor and the rinsed solution was light with a yellowish color.

As compared to unprocessed lupin seeds, a higher content of total and true protein and a lower antinutrient content were found in all variants of germinated seeds. The type of the nitrogen source had a significant influence $(P<0.05)$ on the content of crude ash, crude fiber, nitrogen-free extract compounds and true protein (Tab. 1). Moreover, significant changes $(P<0.05)$ were found in the amino acid composition of protein (Tab. 2) in terms of isoleucine, leucine, methionine, valine, tyrosine, cystine, aspartic acid, glutamic acid and proline as well as nutritional indices of the protein nutritional value - CS $(P=0.001)$ and $\operatorname{EAAI}(P=0.002)$. Cystine + methionine were amino acids limiting the protein synthesis, except for the seeds germinated in a $1 \%$ methionine solution, in which valine was the limiting amino acid. The type of nitrogen had a significant influence $(P<0.05)$ on the antinutrient content (Tab. 3) - oligosaccharides from the raffinose family and alkaloids - and on the structure of these compounds; however, it did not affect the phytate content $(P>0.05)$.
As compared to seeds germinated in water, the seeds germinated in urea had a significantly lower content of crude ash $(P<0.05)$ as well as isoleucine, tyrosine and aspartic acid in the protein - they did contain more crude fibre, the true protein and cystine and glutamic acid in the protein. Moreover, a significantly higher raffinose content $(P<0.05)$ as well as lower alkaloid content $(P<0.05)$ was found in the seeds germinated in urea with a higher content of $130 \mathrm{H}$ lupanine and a lower content of lupanine.

The seeds germinated in a $1 \%$ ammonium sulphate solution were found to contain significantly less crude ash and less amino acids, tyrosine and aspartic acid, in the protein and a higher content of true protein, cystine (approx. 50\%) and glutamic acid in the protein as compared to seeds germinated in water. Moreover, a significantly higher concentration of oligosaccharides (raffinose and verbascose; $P<0.05$ ) was found in seeds germinated in ammonium sulphate. The lupanine content was significantly lower $(P<0.05)$, and the $13 \mathrm{OH}$ lupanine content was higher than in seeds germinated in water; however, the total alkaloid quantity was similar $(P>0.05)$.

The seed germination in nitric acid significantly reduced the crude ash content $(P<0.05)$, its content was the lowest among all the variants, while the content of nitrogen-free compounds and that of the true protein were significantly higher than in seeds germinated in water. Moreover, a significant influence of nitric acid on the protein structure was found. The content of isoleucine, leucine, valine, glutamic acid as well as proline was significantly higher $(P<0.05)$ than in the protein of seeds germinated in water; however, the content of tyrosine and aspartic acid was lower $(P<0.05)$. Moreover, no presence of cystine was found in the protein from these seeds and the methionine content was nearly $50 \%$ lower $(P>0.05)$ than in seeds germinated in water. It had a significant influence of the protein nutritional value indices, which were the lowest for seeds germinated in nitric acids and amounted to: $C S-5.5$ and EAAI 54.5 vs. 28 and 65.5 for seeds germinated in water. Nitric acid did not affect the oligosaccharides and phytate content in the seeds; however, it lowered the alkaloid content significantly, with higher isolupanine content $(P<0.05)$. The alkaloid content in the seeds germinated in nitric acid was the lowest of all the variants.

Seeds germinated in a $1 \%$ methionine solution contained less crude ash and more true protein $(P<0.05)$. The protein of seeds germinated in this solution contained significantly less tyrosine and aspartic acid $(P<0.05)$ and more glutamic acid

Tab. 1 The impact of $\mathrm{N}$-sources and time of germination on the chemical composition of lupin seeds (\% DM).

\begin{tabular}{|c|c|c|c|c|c|c|c|c|c|c|c|c|c|}
\hline \multirow[b]{2}{*}{ Components } & \multirow[b]{2}{*}{$\begin{array}{c}\text { Raw lupin } \\
\text { seeds }\end{array}$} & \multicolumn{7}{|c|}{ N-sources $(N)$} & \multicolumn{3}{|c|}{ Time of germination $(T)$} & \multicolumn{2}{|c|}{$\begin{array}{c}\text { Mean effects } \\
P<0.05\end{array}$} \\
\hline & & Water & Urea & $\begin{array}{c}\text { Ammonium } \\
\text { sulfate }\end{array}$ & $\begin{array}{c}\text { Nitric } \\
\text { acid }\end{array}$ & Methionine & $\begin{array}{c}\text { Yeast } \\
\text { extract }\end{array}$ & SEM & 3 days & 4 days & SEM & $N$ & $T$ \\
\hline Crude protein & 33.03 & 40.59 & 40.97 & 41.75 & 37.73 & 39.02 & 41.35 & 0.40 & $39.42^{\mathrm{B}}$ & $41.05^{\mathrm{A}}$ & 0.69 & NS & 0.034 \\
\hline Crude ash & 3.88 & $4.49^{\mathrm{a}}$ & $2.99^{c}$ & $3.16^{\mathrm{c}}$ & $1.29^{\mathrm{d}}$ & $3.90^{\mathrm{b}}$ & $4.35^{\mathrm{a}}$ & 0.11 & 3.41 & 3.31 & 0.06 & 0.001 & NS \\
\hline Crude fibre & 17.41 & $17.35^{\mathrm{bc}}$ & $19.96^{\mathrm{a}}$ & $16.34^{\mathrm{c}}$ & $18.24^{\mathrm{b}}$ & $17.85^{\mathrm{bc}}$ & $17.81^{\mathrm{bc}}$ & 0.40 & 17.92 & 17.93 & 0.23 & 0.016 & NS \\
\hline Ether extract & 4.64 & 4.70 & 5.99 & 5.41 & 4.67 & 7.34 & 5.13 & 0.84 & 5.2 & 5.90 & 0.49 & NS & NS \\
\hline NFE & 36.76 & $32.89^{b}$ & $30.10^{b}$ & $33.35^{\mathrm{b}}$ & $38.08^{a}$ & $31.90^{\mathrm{b}}$ & $31.36^{\mathrm{b}}$ & 0.94 & $34.05^{A}$ & $31.85^{\mathrm{B}}$ & 0.54 & 0.016 & 0.035 \\
\hline True protein & 24.26 & $23.38^{b}$ & $31.71^{\mathrm{a}}$ & $27.77^{\mathrm{a}}$ & $30.98^{a}$ & $29.97^{a}$ & $27.78^{a}$ & 1.07 & 28.95 & 28.23 & 0.62 & 0.020 & NS \\
\hline
\end{tabular}

A, B - value in rows differs significantly in the time of germination $(T)$ at $P<0.05$; ${ }^{\mathrm{a}, \mathrm{b}, \mathrm{c}, \mathrm{d}}-$ value in rows differs significantly in the type of $\mathrm{N}-$ sources $(N)$ at $P<0.05$. NFE - nitrogen-free extracts; NS - not significant; SEM - standard error of mean. 
Tab. 2 The impact of $\mathrm{N}$-sources and time of germination on amino acids composition (g/100 $\mathrm{g}$ of protein) and protein value (CS, EAAI) of lupin products.

\begin{tabular}{|c|c|c|c|c|c|c|c|c|c|c|c|c|c|}
\hline \multirow[b]{2}{*}{ Components } & \multirow{2}{*}{$\begin{array}{c}\text { Raw } \\
\text { lupin } \\
\text { seeds }\end{array}$} & \multicolumn{7}{|c|}{ N-sources $(N)$} & \multicolumn{3}{|c|}{ Time of germination $(T)$} & \multicolumn{2}{|c|}{ Mean effects } \\
\hline & & Water & Urea & $\begin{array}{l}\text { Ammonium } \\
\text { sulfate }\end{array}$ & $\begin{array}{l}\text { Nitric } \\
\text { acid }\end{array}$ & Methionine & $\begin{array}{c}\text { Yeast } \\
\text { extract }\end{array}$ & SEM & 3 days & 4 days & SEM & $N$ & $T$ \\
\hline Arginine & 12.17 & 8.22 & 9.24 & 9.41 & 8.71 & 10.22 & 9.46 & 0.64 & 9.46 & 8.95 & 0.37 & NS & NS \\
\hline Phenylalanine & 3.48 & 4.07 & 4.11 & 3.56 & 3.90 & 3.66 & 3.86 & 0.20 & 3.89 & 3.83 & 0.11 & NS & NS \\
\hline Histidine & 3.75 & 3.35 & 3.00 & 2.88 & 3.04 & 2.61 & 3.20 & 0.28 & 2.91 & 3.11 & 0.16 & NS & NS \\
\hline Isoleucine & 3.54 & $3.69^{\mathrm{c}}$ & $3.90^{\mathrm{b}}$ & $3.66^{\mathrm{c}}$ & $4.17^{\mathrm{a}}$ & $3.70^{c}$ & $3.60^{c}$ & 0.05 & 3.79 & 3.78 & 0.03 & 0.002 & NS \\
\hline Leucine & 5.90 & $6.18^{\mathrm{bc}}$ & $6.52^{\mathrm{b}}$ & $6.27^{\mathrm{bc}}$ & $7.05^{\mathrm{a}}$ & $6.27^{b c}$ & $5.97^{c}$ & 0.12 & 6.40 & 6.35 & 0.07 & 0.011 & NS \\
\hline Lysine & 5.26 & 4.50 & 4.88 & 3.92 & 4.80 & 4.27 & 4.04 & 0.21 & 4.50 & 4.29 & 0.12 & NS & NS \\
\hline Methionine (M) & 0.53 & $0.67^{\mathrm{b}}$ & $0.66^{\mathrm{b}}$ & $0.41^{\mathrm{b}}$ & $0.32^{\mathrm{b}}$ & $3.24^{\mathrm{a}}$ & $0.55^{\mathrm{b}}$ & 0.21 & 0.95 & 0.99 & 0.12 & 0.001 & NS \\
\hline Threonine & 3.27 & 3.33 & 3.26 & 3.38 & 3.21 & 3.27 & 3.46 & 0.05 & 3.28 & 3.35 & 0.03 & NS & NS \\
\hline Valine (V) & 3.57 & $3.76^{\mathrm{b}}$ & $3.80^{\mathrm{ab}}$ & $3.64^{\mathrm{b}}$ & $4.13^{\mathrm{a}}$ & $3.53^{\mathrm{b}}$ & $3.69^{\mathrm{b}}$ & 0.09 & 3.75 & 3.76 & 0.05 & 0.048 & NS \\
\hline Cystine (C) & 1.38 & $0.96^{c}$ & $1.20^{\mathrm{c}}$ & $1.50^{\mathrm{b}}$ & $0.00^{\mathrm{d}}$ & $2.31^{\mathrm{a}}$ & $1.51^{\mathrm{b}}$ & 0.08 & 1.18 & 1.31 & 0.04 & 0.001 & NS \\
\hline Tyrosine & 3.74 & $5.18^{\mathrm{a}}$ & $3.60^{\mathrm{c}}$ & $4.30^{\mathrm{bc}}$ & $2.89^{\mathrm{d}}$ & $3.92^{b c}$ & $4.48^{\mathrm{ab}}$ & 0.23 & 3.97 & 3.98 & 0.13 & 0.004 & NS \\
\hline Alanine & 3.03 & 4.76 & 3.77 & 3.94 & 3.53 & 3.55 & 3.86 & 0.24 & 3.78 & 4.02 & 0.14 & NS & NS \\
\hline Glycine & 3.98 & 3.52 & 3.83 & 3.93 & 4.14 & 3.65 & 3.57 & 0.13 & 3.61 & 3.74 & 0.07 & NS & NS \\
\hline Aspartic acid & 8.95 & $15.71^{\mathrm{a}}$ & $9.12^{\mathrm{b}}$ & $9.91^{\mathrm{b}}$ & $9.46^{\mathrm{b}}$ & $9.12^{b}$ & $14.94^{\mathrm{a}}$ & 1.17 & 10.75 & 12.00 & 0.67 & 0.027 & NS \\
\hline Glutamic acid & 22.74 & $16.68^{c}$ & $23.49^{\mathrm{a}}$ & $24.88^{a}$ & $23.30^{\mathrm{ab}}$ & $21.77^{a b}$ & $18.99 \mathrm{bc}$ & 1.15 & 22.03 & 21.00 & 0.66 & 0.024 & NS \\
\hline Proline & 5.58 & $5.90^{\mathrm{b}}$ & $6.16^{\mathrm{b}}$ & $7.04^{\mathrm{ab}}$ & $8.52^{\mathrm{a}}$ & $5.53^{\mathrm{b}}$ & $5.40^{\mathrm{b}}$ & 0.45 & 6.62 & 6.22 & 0.26 & 0.026 & NS \\
\hline Serine & 4.39 & 4.54 & 4.50 & 4.43 & 4.34 & 4.43 & 4.44 & 0.09 & 4.42 & 4.47 & 0.05 & NS & NS \\
\hline$C S$ & 33 & $28.0^{c}$ & $32.5^{\mathrm{bc}}$ & $33.0^{\mathrm{bc}}$ & $5.5^{\mathrm{d}}$ & $48.0^{\mathrm{a}}$ & $35.5^{\mathrm{b}}$ & 1.7 & 30.8 & 30.0 & 1.0 & 0.001 & NS \\
\hline Limiting amino acid & $M+C$ & $M+C$ & $M+C$ & $M+C$ & $M+C$ & $\mathrm{~V}$ & $M+C$ & - & - & - & - & - & - \\
\hline EAAI & 62 & $65.5^{\mathrm{b}}$ & $66.5^{\mathrm{b}}$ & $64.5^{\mathrm{b}}$ & $54.5^{\mathrm{c}}$ & $72.0^{a}$ & $65.0^{\mathrm{b}}$ & 0.7 & 64.8 & 64.5 & 0.4 & 0.002 & NS \\
\hline
\end{tabular}

A, B - value in rows differs significantly in the time of germination $(T)$ at $P<0.05 ;$ a, b, , d - value in rows differs significantly in the type of Nsources $(N)$ at $P<0.05$. NS - not significant; SEM - standard error of mean.

Tab. 3 The impact of N-sources and time of germination on oligosaccharides, alkaloids and phytate concentrations in seeds after germination.

\begin{tabular}{|c|c|c|c|c|c|c|c|c|c|c|c|c|c|}
\hline \multirow[b]{2}{*}{ Components } & \multirow{2}{*}{$\begin{array}{l}\text { Raw } \\
\text { lupin } \\
\text { seeds }\end{array}$} & \multicolumn{7}{|c|}{ N-sources $(N)$} & \multicolumn{3}{|c|}{$\begin{array}{c}\text { Time of germination } \\
\text { (T) }\end{array}$} & \multicolumn{2}{|c|}{$\begin{array}{l}\text { Mean } \\
\text { effects }\end{array}$} \\
\hline & & Water & Urea & $\begin{array}{l}\text { Ammonium } \\
\text { sulfate }\end{array}$ & $\begin{array}{c}\text { Nitric } \\
\text { acid }\end{array}$ & Methionine & $\begin{array}{c}\text { Yeast } \\
\text { extract }\end{array}$ & SEM & 3 days & 4 days & SEM & $N$ & $T$ \\
\hline Total oligosaccharides (\% DM) & 7.36 & $0.38^{\mathrm{cd}}$ & $0.59^{b c}$ & $0.97^{\mathrm{a}}$ & $0.22^{\mathrm{d}}$ & $1.12^{\mathrm{a}}$ & $0.67^{\mathrm{b}}$ & 0.08 & $0.78^{\mathrm{A}}$ & $0.56^{\mathrm{B}}$ & 0.04 & 0.002 & 0.019 \\
\hline Raffinose (\% DM) & 1.22 & $0.00^{c}$ & $0.09^{\mathrm{a}}$ & $0.04^{\mathrm{b}}$ & $0.01^{\mathrm{c}}$ & $0.00^{\mathrm{c}}$ & $0.00^{c}$ & 0.01 & 0.03 & 0.01 & 0.01 & 0.001 & NS \\
\hline Stachyose (\% DM) & 4.15 & $0.38^{\mathrm{bc}}$ & $0.39^{\mathrm{abc}}$ & $0.58^{\mathrm{ab}}$ & $0.18^{\mathrm{c}}$ & $0.62^{\mathrm{a}}$ & $0.30^{\mathrm{c}}$ & 0.06 & $0.48^{\mathrm{A}}$ & $0.33^{\text {B }}$ & 0.03 & 0.021 & 0.026 \\
\hline Verbaskose (\% DM) & 1.99 & $0.00^{\mathrm{b}}$ & $0.11^{\mathrm{b}}$ & $0.35^{\mathrm{a}}$ & $0.03^{\mathrm{b}}$ & $0.50^{\mathrm{a}}$ & $0.37^{\text {a }}$ & 0.06 & 0.24 & 0.21 & 0.04 & 0.012 & NS \\
\hline Total alkaloids (\% DM) & 0.044 & $0.048^{\text {a }}$ & $0.014^{\mathrm{b}}$ & $0.031^{\mathrm{a}}$ & $0.004^{\mathrm{b}}$ & $0.043^{\mathrm{a}}$ & $0.035^{\mathrm{a}}$ & 0.005 & 0.031 & 0.028 & 0.01 & 0.007 & NS \\
\hline Angustifoline (\% TA) & 6.30 & 7.08 & 5.26 & 6.01 & 11.40 & 9.13 & 8.81 & 1.57 & 8.57 & 7.32 & 0.91 & NS & NS \\
\hline Isolupanine (\% $\mathrm{TA}$ ) & 5.06 & $4.92^{\mathrm{b}}$ & $5.07^{\mathrm{b}}$ & $4.11^{\mathrm{b}}$ & $6.22^{\mathrm{a}}$ & $4.30^{\mathrm{b}}$ & $4.42^{\mathrm{b}}$ & 0.29 & 4.75 & 4.93 & 0.17 & 0.026 & NS \\
\hline Lupanine (\% TA) & 70.42 & $68.90^{a}$ & $61.23^{b}$ & $61.78^{b}$ & $64.34^{\mathrm{ab}}$ & $60.47^{b}$ & 65.38 ab & 1.43 & 63.39 & 64.01 & 0.82 & 0.050 & NS \\
\hline 13OHlupanine (\% TA) & 18.21 & $19.00^{\mathrm{d}}$ & $28.43^{a}$ & $28.09^{\mathrm{ab}}$ & $18.03^{\mathrm{d}}$ & $26.99^{b}$ & $21.37^{\mathrm{c}}$ & 0.605 & 23.26 & 23.74 & 0.35 & 0.001 & NS \\
\hline Phytate (\% DM) & 0.58 & 0.47 & 0.47 & 0.53 & 0.39 & 0.45 & 0.49 & 0.41 & 0.47 & 0.46 & 0.02 & NS & NS \\
\hline
\end{tabular}

A, B - value in rows differs significantly in the time of germination $(T)$ at $P<0.05 ;$, b, c, d - value in rows differs significantly in the type of $\mathrm{N}$ sources $(N)$ at $P<0.05$. NS - not significant; SEM - standard error of mean; TA - Total alkaloids.

than the protein from seeds germinated in water. Moreover, a nearly fivefold increase in the methionine content was found in the seeds, while the cystine content was 2.5 times higher $(P<0.05)$. It had a significant influence $(P<0.05)$ on the protein nutritional value indices, which were the highest for seeds germinated in the methionine solution and had the following values: $C S=48$ and $E A A I=72$. Valine was the limiting amino acid. The seeds germinated in a methionine solution had the highest oligosaccharides content $(P<0.05)$, especially of stachyose and verbascose; however, no influence of methionine on the 
phytic phosphorus content and the total alkaloid concentration was confirmed, despite a decrease in the lupanine content and increase in the $130 \mathrm{H}$ lupanine content $(P<0.05)$.

The proximate composition of seeds germinated in yeast extract did not differ from seeds germinated in water; but they did contain more true protein $(P<0.05)$. The amino acid composition of the protein was similar, except for the methionine concentration - its content was by $50 \%$ higher, which increased the CS index to 35.5 vs. 28.0. A significantly higher oligosaccharide content was found in seeds germinated in yeast extract $(P<0.05)$, especially of verbascose; however, the phytate and total alkaloid content was similar, with a higher concentration of $13 \mathrm{OHlupanine.}$

The extension of the germination time from 3 to 4 days had a significant influence on an increase in the protein content $(P=0.034)$ and a decrease in the concentration of oligosaccharides from the raffinose family $(P=0.019)$, mostly stachyose $(P=0.026)$, as well as a decrease in the content of nitrogen-free compounds $(P=0.035)$. No interaction between the nitrogen source and the germination time was found.

\section{Discussion}

Selective preparations, which do not have contaminated seeds with heavy metal salts, and preparations containing micronutrients and growth substances have an advantageous influence on plant germination. Concentrated, non-selective substances have a negative effect as their cause sprout deformation. The group of well-known germination stimulators used in research includes thiourea, urea, potassium nitrate as well as glutathione, glutamine and vitamins $[15,19]$. According to Pérez-Fernández et al. [14], the germination reaction of plants to the medium composition may vary; however, the quantity and form of nitrogen in the medium have the greatest influence on the process, which is confirmed by this research. Out of 52 plants examined by Luna and Moreno [15], potassium nitrate had a (positive or negative) influence (in the amount of $20 \mathrm{mM}$ ) on only approx. $25 \%$ of species.

In the research presented, the nitrogen substances were selected so as to ensure the availability of various chemical forms of nitrogen: $(i)$ inorganic - anion $\left(\mathrm{NO}_{3}\right)^{-}$in nitric acid and cation $\left(\mathrm{NH}_{4}\right)^{+}$in ammonium sulphate, $(\boldsymbol{i i})$ organic - urea, (iii) amino acid - methionine and, (iv) protein - yeast extract. Due to the same $1 \%$ content of the individual compounds in aqueous solutions, the nitrogen content varied and it amounted to $0.46 \mathrm{~g} \mathrm{~N} / 100 \mathrm{ml}$ of the solution for urea, $0.21 \mathrm{~g} \mathrm{~N} / 100 \mathrm{ml}$ - for ammonium sulphate and nitric acid and for the methionine and yeast extract solutions $-0.10 \mathrm{~g} \mathrm{~N} / 100 \mathrm{ml}$. These levels are similar to those used by Bremner and Kogmeier [13]; however, soil was used as the substrate in their research. Presented research should be treated as preliminary. Due to the unavailability of data concerning the influence of the concentrations of the selected compounds on the sprout composition, it was not decided to equalise the solution concentrations in terms of the nitrogen content. These compounds are, in addition to being a source of nitrogen, also a source of carbon (urea, methionine, yeast extract), sulphur (ammonium sulphate, methionine, yeast extract) and other minerals (yeast extract), which may affect the germination process in various ways, as shown in this research. The $1 \%$ content of each of the selected chemical compounds containing various forms of nitrogen had an inhibitory effect on sprout development; however, the degree of the inhibition varied (from 45 to 95\%). Hardly any seeds sprouted in the $1 \%$ solutions of urea and nitric acid, while their growth in the methionine solution was slightly more rapid. Approx. 50\% of the seeds germinated in the solutions of ammonium sulphate and yeast extract. Research by other authors shows that inorganic forms of nitrogen (ammonium and nitrate nitrogen) are incomparably better assimilable by plants than its organic compounds, except for urea, asparagine and glutamine [22]. In the research presented, the source of nitrogen did not have a significant influence on nitrogen assimilation (understood as an increase in the protein content) in germinated seeds and ammonium sulphate and urea caused a similar increase in the protein content, despite the different rates of sprout growth. It probably results from inappropriate selection of the concentrations of the individual nitrogen compounds. Similar conclusions were drawn by Bremner and Krogmeier [13], who germinated cereal seeds in a stable substrate with the addition of various nitrogen compounds [urea, ammonium sulphate, ammonium carbonate, ammonia, sodium nitrate (III) and (V)] in the amount of $0.25 ; 0.5$ and $1.0 \mathrm{mg} \mathrm{N} / \mathrm{g}$ of the substrate. The highest concentration of urea inhibited the germination completely, while none of the ammonium sulphate concentrations influenced the effectiveness of seed germination. The aforementioned authors also found that ammonia has a harmful effect on the sprouts. It is neutralized in plants by forming glutamine and asparagine or urea, which is a source of nitrogen used for building proteins [22]. Under natural conditions, this compound accumulates in cells in small amounts, while its higher concentrations may have a toxic effect. This is confirmed by the research presented here in which the added urea decomposed to ammonia, probably under the influence of native urease, which was confirmed by the odor of the sprouts and the rinsed solution. This finding is consistent with the observations made by Bremner and Krogmeier [13], who found that the addition of pure urea to the substrate at a concentration of over $1.0 \mathrm{mg} \mathrm{N} / \mathrm{g}$ of the substrate had an inhibitory effect on the effectiveness of cereal seed germination and it inhibited this process completely at a concentration of $2.0 \mathrm{mg}$ $\mathrm{N} / \mathrm{g}$. Moreover, the addition of urease to the urea-containing substrate results in a complete inhibition of germination. As shown by research by Borek et al. [23], urease plays the key role in the germination process and its activity during germination of lupin seeds is high.

The present author's own research reveals that also nitric acid significantly inhibited sprout development, which probably results from the chemical character of this compound and the low $\mathrm{pH}$ value of the solution used. This is consistent with findings by Hernández-Ferretiz et al. [24], who observed germ destruction following the use of sulphuric acid. Sulphuric and nitric acid, concentrated or diluted, is often used in practice for several dozen seconds up to even 24 hours as scarifying factors, which accelerate the germination of seeds of various plant species. On the other hand, moist and swollen seeds may be severely damaged or even die under such conditions, which is confirmed by the low number of germinated seeds and the changes in the seed composition, which are connected with, for example, the rinsing of mineral compounds, degradation of amino acid (cystine) or alkaloids. Moreover, Bremner and Krogmeier [13] found that nitric acid salts might influence cereal seeds in a variety of ways. Sodium nitrate (V) did not affect the seed germination ability; however, sodium nitrate (III) at a concentration of 0.5 and $1.0 \mathrm{mg} \mathrm{N} / \mathrm{g}$ of the substrate had an inhibitory effect. 
Research on sterile cultures has shown that Leguminosae plants (e.g. pea seeds) assimilate some amino acids quite well: glycine, $\alpha$-alanine, glutamic and aspartic acids if they are the only sources of nitrogen [25]. Other amino acids, on the other hand, have a negative or even toxic effect on plants and germs, e.g. glycine can be assimilated, but the development of roots was inhibited; phenylalanine and tyrosine had a toxic effect; and plants grew poorly on a substrate with the addition of lysine. The use of methionine in the author's own research resulted in a poor growth of sprouts as compared with seeds germinated in water, which confirms the considerable inhibitory strength of methionine or its inappropriate concentration, which requires further clarification. According to Grzesiuk [22], replacement of individual amino acids with their mixture results in a poorer seedling development than the use of mineral nitrogen. Other scientific research also provides evidence that treating seeds with, e.g. alfalfa leaf powder, casein or peptone containing various nitrogen components resulted in a decrease in the germination ability [25]. This phenomenon is probably connected with the accumulation of poisonous products of organic compound decomposition. Partially, a similar effect was observed for yeast extract, which contained all necessary amino acids, as well as ones with a well-known inhibitory effect. Observations were made, which confirm the opinion that the germination ability of plants depends on the species as well as the form and concentration of the available nitrogen; hence, the selection of the qualitative and quantitative composition of the substrate seems to be of key importance in this case.

All research quoted above focuses basically only on the influence of physical and chemical factors on the seed germination effectiveness; however, no data are available on changes in their chemical composition, especially in terms of their nutritional value. The initial seed germination stage is characterized by an abrupt increase in respiration and intense water intake. The general balance of metabolism is negative during the first germination stage and a decrease in the dry mass of germinating seeds may reach up to $20 \%$ [25]. Seed storage reserves are respiration substrates in germinating seeds. Initially, these are simple sugars occurring in lupin seeds in small amounts (approx. 1-2\%), next, reserves of oligosaccharides, mostly sugars from the raffinose family (approx. 1\%), polysaccharides of cell walls (lignin, approx. 1\%), and finally basic reserve substances in the seed - polysaccharides, lipids and reserve proteins. This is confirmed by a significant decrease in carbohydrate content, especially oligosaccharides, that has been observed in this research. These compounds undergo degradation and are used as a source of carbon for the biosynthesis of other compounds $[5,26]$. The addition of nitrogen compounds during germination also influenced transformations of oligosaccharides, which implies their higher level in all research materials (except for nitric acid) as compared with seeds germinated in water. On the other hand, the presence of an additional source of nitrogen had a stimulatory effect on nitrogen transformations, which is reflected in a significantly higher concentration of true protein and a lower content of lupin alkaloids. During seed germination in water, reserve proteins are the source of food for the sprout. During the swelling process, they undergo hydrolytic and oxidative decomposition to form free amino acids as well as glutamine and asparagine amides, which are the source material for the synthesis of new proteins. Aspartic acid and glutamic acid are the first products of ammonia assimilation as a result of deamination of nitrogen compounds, followed by alanine, valine and leucine [27]. The presence of glutamine and asparagine as well as arginine in the seeds allows for transamination and creation of new amino acids [28]. Lupin germinated in darkness may contain up to $10 \%$ of asparagine in dry mass. In the author's own research, the aspartic acid content in the seed protein increased by approx. 50\% during seed germination in water and yeast extract and a significant increase in the glutamic acid concentration was recorded in seeds germinated in all solutions containing an additional source of nitrogen as compared with water, which confirms the occurrence of dynamic metabolic transformations. In the case of arginine, which is a reserve substance, a decrease in its content in the protein is observed. During germination, arginine is transformed into a keto acid and it is used further in the Krebs cycle; it also undergoes enzymatic transformations to form polyamides, ornithine, ammonia and carbon dioxide [23]. The results of research by Dougall [29] show that a range of exogenous amino acids are used for synthesis of proteins much more easily than endogenous amino acids formed from glucose. These include histidine, arginine, threonine, methionine, isoleucine, phenylalanine and tyrosine. The results of seed germination in a solution of methionine and yeast extract also seem to confirm the hypothesis that exogenous amino acids may be assimilated by plant tissues and included in the protein without prior degradation. When seeds were germinated in a methionine solution, this amino acid was used for protein synthesis, which is confirmed by an increase in the protein concentration in the seeds and methionine and cystine in the protein. Insofar as an increase in the methionine concentration in the sprouts may result from the amino acid being absorbed directly from the aqueous solution, the simultaneous increase in the cystine concentration is difficult to explain. It seems that these amino acids must have been transformed here. A similar relationship was found in seeds germinated in yeast extract, which contained methionine and cystine amongst other things. The methionine level did not increase in the germinated seeds; however, a significant increase in the cystine level was observed, which probably resulted from direct cystine assimilation or from the biosynthesis of this amino acid and obtaining mutual relations of sulphur amino acids in the germinated lupin seeds, which is characteristic of this species. This may also imply that cystine is more easily assimilated than methionine. At the same time, a significant increase in the cystine concentration was also found when seeds were germinated in an ammonium sulphate solution. It can be concluded from this fact that the compound was used by the seeds not only as a source of nitrogen, but also as a source of sulphur and the level of sulphur amino acids in the seeds depends on the availability of this element. Thus, the presence of sulphur may be a factor limiting the sulphur amino acid content, which shows the necessity of enriching the substrate with this element. This hypothesis is confirmed by the fact that there was no significant increase in the cystine content in the seeds germinated in a urea solution. From the point of view of the nutritional value of sprouts, these observations are extremely important because the nutritional value of protein increases significantly together with an increase in the sulphur amino acid concentration, which is reflected by the values of the $C S$ and EAAI indices. In contrast, a significant decrease in the protein nutritional value indices was found in seeds germinated in the nitric acid solution, in which complete degradation of cystine occurred. Sulphur amino acids are amino acids, which limit protein synthesis and their low content limits the use of lupin seeds in farm animal nutrition. It should be noted that antinutrients also have a negative effect on monogastric 
animals, which undergo considerable degradation during the germination process. As a result of germination (in water and in nitrogen solutions), the sugar content from the raffinose family decreased by $85-97 \%$, which is advantageous due to the lack of endogenous enzymes in animals, which could degrade these compounds from the feed. The majority of authors also observe a decrease in the alkaloid concentration during seed germination in water, depending on the lupin species, germination conditions and germination time [5]. In the research presented, seed germination in water did not influence the reduction of the alkaloid content, while the decrease in the level of alkaloids, and especially of lupanine, ranged from 10 to $90 \%$ in the presence of an additional source of nitrogen.

Chilomer et al. [6] found that the germination of lupin seeds in water did not have a positive influence on the content and intestinal digestibility of amino acids or on the feed intake and use by growing pigs. It does result from the research conducted, however, that additional sources of nitrogen (as well as additional sources of carbon and sulphur) can be used in the germination process for protein synthesis, and in particular for the synthesis of sulphur amino acids, which considerably influences their nutritional value and, as a result, also the feed usefulness of lupin sprouts. The possibility of enriching lupin sprouts with sulphur amino acids appears to be a likely opportunity for the improvement of their nutritional value, especially with a simultaneous reduction in the antinutrient concentrations. Nevertheless, the effect largely depends on the appropriate selection of the qualitative and quantitative composition of the substrate, which will ensure not only the desired chemical composition, but also proper growth of sprouts. Currently, ammonium sulphate and yeast extract seem to be the most promising from among the nitrogen sources tested; however, further research is needed to confirm this thesis.

\section{Acknowledgments}

This work was supported by financial statute of Department of Animal Nutrition and Feed Management, Poznań University of Life Sciences.

\section{Authors' contributions}

The following declarations about authors' contributions to the research have been made: idea of the research, preparation of scheme of the research and analytical technique, conducting of chemical analysis, supervised experience, statistical analysis, preparation of the article: MKP; making experience, chemical analysis, development results, calculations, preparation of materials for the article: EW; chemical analysis, preparation of literature: AZ; supervision, review preliminary: AF.

\section{References}

1. EU Resolution of 8 March 2011 on EU agriculture and international trade [2010/2110(INI)]. Off J Eur Union. 2012;55(C 199E):48-64. http://dx.doi. org/10.3000/1977091X.C_2012.199.eng

2. Jezierny D, Mosenthin R, Bauer E. The use of grain legumes as a protein source in pig nutrition: a review. Anim Feed Sci Technol. 2010;157(34):111-128. http://dx.doi.org/10.1016/j.anifeedsci.2010.03.001

3. Benchaar C, Vernay M, Bayourthe C, Moncoulon R. Effects of extrusion of whole horse beans on protein digestion and amino acid absorption in dairy cows. J Dairy Sci. 1994;77(5):1360-1371. http://dx.doi.org/10.3168/ jds.S0022-0302(94)77075-2

4. Kasprowicz-Potocka M, Borowczyk P, Chilomer K, Frankiewicz A. The impact of yeast on chemical composition of lupin seeds. In: Lupin crops - an opportunity for today a promise for the future. 13-th International Lupin Conference, 6-10 June 2011, Poznań, Poland. 2011. p. L-35.

5. Chilomer K, Zaleska K, Ciesiołka D, Gulewicz P, Frankiewicz A, Gulewicz K. Changes in the alkaloid, a-galactoside and protein fractions content during germination of different lupin species. Acta Soc Bot Pol. 2010;79(1):11-20. http://dx.doi.org/10.5586/asbp.2010.002

6. Chilomer K, Kasprowicz-Potocka M, Gulewicz P, Frankiewicz A. The influence of lupin seed germination on the chemical composition and standardized ileal digestibility of protein and amino acids in pigs: impact of lupin seed germination on digestibility in pigs. J Anim Physiol Anim Nutr. 2013;97(4):639-646. http://dx.doi.org/10.1111/j.1439-0396.2012.01304.x

7. Bari L, Enomoto K, Nei D, Kawamoto S. Development of effective seed decontamination technology to inactivate pathogens on mung bean seeds and its practical application in Japan. Jpn Agric Res Q. 2011;45(2):153-161. http://dx.doi.org/10.6090/jarq.45.153

8. Fashui H, Ling W, Chao L. Study of lanthanum on seed germination and growth of rice. Biol Trace Elem Res. 2003;94(3):273-286. http://dx.doi. org/10.1385/BTER:94:3:273

9. Gulewicz P, Martínez-Villaluenga C, Frias J, Ciesiołka D, Gulewicz K, Vidal-Valverde C. Effect of germination on the protein fraction composition of different lupin seeds. Food Chem. 2008;107(2):830-844. http://dx.doi. org/10.1016/j.foodchem.2007.08.087

10. Molberg ES. Injurious effects of fertilizers applied with the seed on the emergence of flax. Can J Soil Sci. 1961;41(1):35-43. http://dx.doi. org/10.4141/cjss61-006

11. Młodzianowska D. Wpływ niektórych substancji nieorganicznych na kiełkujące ziarno i wschody kukurydzy w warunkach niskich temperatur. Hod. Roślin Aklim. Nasienn. 1962;6(3):257-310.

12. Mayer AM, Poljakoff-Mayber A. The germination of seeds. Oxford: Pergamon Press; 1961.

13. Bremner JM, Krogmeier MJ. Evidence that the adverse effect of urea fertilizer on seed germination in soil is due to ammonia formed through hydrolysis of urea by soil urease. Proc Natl Acad Sci USA. 1989;86(21):8185-8188. http://dx.doi.org/10.1073/pnas.86.21.8185

14. Pérez-Fernández MA, Calvo-Magro E, Montanero-Fernández J, OyolaVelasco JA. Seed germination in response to chemicals: effect of nitrogen and $\mathrm{pH}$ in the media. J Env. Biol. 2006;27(1):13-20.

15. Luna B, Bremner JM. Light and nitrate effects on seed germination of Mediterranean plant species of several functional groups. Plant Ecol. 2008;203(1):123-135. http://dx.doi.org/10.1007/s11258-008-9517-8

16. Zielińska-Dawidziak M, Piasecka-Kwiatkowska D, Twardowski T. Wpływ jonów $\mathrm{Fe}^{2+}$ działających na kiełkujące nasiona soi, lucerny oraz ziarniaki pszenicy na zawartość skrobi i cukrów redukujących. Nauka Przyr Technol. 2010;4(2):27.

17. Frias J, Gulewicz P, Martínez-Villaluenga C, Pilarski R, Blazquez E, Jiménez $\mathrm{B}$, et al. Influence of germination with different selenium solutions on nutritional value and cytotoxicity of lupin seeds. J Agric Food Chem. 2009;57(4):1319-1325. http://dx.doi.org/10.1021/jf8028368

18. Nawaz F, Ashraf MY, Ahmad R, Waraich EA. Selenium (Se) seed priming induced growth and biochemical changes in wheat under water deficit conditions. Biol Trace Elem Res. 2012;151(2):284-293. http://dx.doi. org/10.1007/s12011-012-9556-9

19. Monaco TA, Mackown CT, Johnson DA, Jones TA, Norton JM, Norton JB, et al. Nitrogen effects on seed germination and seedling growth. J Range Manage. 2006;56(6):646-653.

20. AOAC. Official methods of analysis of the Association of Official Analytical Chemists, Vol. 1. 18th ed. Gaithersburg MD: Association of Official Analytical Chemists; 2007. 
21. Zalewski K, Lahuta LB, Horbowicz M. The effect of soil drought on the composition of carbohydrates in yellow lupin seeds and triticale kernels. Acta Physiol Plant. 2001;23(1):73-78. http://dx.doi.org/10.1007/ s11738-001-0025-x

22. Grzesiuk S. Fizjologia nasion. Warsaw: PWRiL; 1967.

23. Borek S, Morkunas I, Ratajczak W, Ratajczak L. Metabolism of amino acids in germinating yellow lupin seeds III. Breakdown of arginine in sugarstarved organs cultivated in vitro. Acta Physiol Plant. 2001;23(2):141-148. http://dx.doi.org/10.1007/s11738-001-0001-5

24. Hernández Ferretiz E, K-yeneida Rivera Meléndez R, Salinas Pérez FC, Rodríguez Monroy M, Bermúdez Torres K. Effect of scarification treatments on germination of Lupinus montanus HBK seeds. In: Palta JA, Berger JD, editors. Lupins for health and wealth. Proceedings of the 12th international lupin conference, Fremantle, Western Australia 14-18 September 2008. Canterbury: International Lupin Association; 2008. p. 405-409.
25. Kretowicz W. Przemiany azotu w roślinach. Warsaw: PWRiL; 1977.

26. Vidal-Valverde C, Frias J, Sierra I, Blazquez I, Lambein F, Kuo YH. New functional legume foods by germination: effect on the nutritive value of beans, lentils and peas. Eur Food Res Technol. 2002;215(6):472-477. http:// dx.doi.org/10.1007/s00217-002-0602-2

27. Genix P, Bligny R, Martin JB, Douce R. Transient accumulation of asparagine in sycamore cells after a long period of sucrose starvation. Plant Physiol. 1990;94(2):717-722. http://dx.doi.org/10.1104/pp.94.2.717

28. Bewley JD, Black M. Seeds: physiology of development and germination. 2nd ed. New York NY: Plenum Press; 1994.

29. Dougall DK. The biosynthesis of protein amino acids in plant tissue culture I. Isotope competition experiments using glucose-U-C14 and the protein amino acids. Plant Physiol. 1965;40(5):891-897. http://dx.doi. org/10.1104/pp.40.5.891 